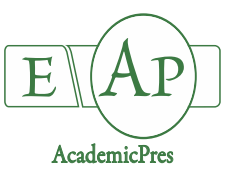

Ozsan T and Onus AN (2020)

Notulae Botanicae Horti Agrobotanici Cluj-Napoca 48(3):1210-1220

DOI: $10.15835 /$ nbha48312004

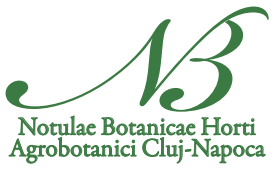

\title{
Comparative study on in vitro micropropagation response of seven globe artichoke [Cynara cardunculus var. scolymus (L.) Fiori] cultivars: open-pollinated cultivars $v s \mathrm{~F}_{1}$ hybrids
}

\author{
Tugce OZSAN, Ahmet N. ONUS*
}

Akdeniz University, Faculty of Agriculture, Department of Horticulture, Dumlupinar Bulvart, 07070 Antalya, Turkey; tugceozsan@akdeniz.edu.tr; onus@akdeniz.edu.tr ("corresponding author)

\begin{abstract}
Globe artichoke [Cynara cardunculus var. scolymus (L.) Fiori] growing has gained commercial importance in recent years due to its consumption as food. It has also started to attract attention in pharmaceutics. Due to globe artichoke's stated importance, growers need large amount of pathogen-free, healthy starting materials for production. Stated material will maximize the yield while minimizing the costs. Hybrid cultivars have uniform in height and maturity and could be harvested concurrently; on the other hand, an open-pollinated cultivar would have useful potential that could be smoothly produced locally at a lower cost. In vitro micropropagation enabling these goals as it serves large scale, fast, reliable and realistic alternative method to classic propagation via offshoots. The aim of the present study was to comparatively evaluate the micropropagation efficiency of two important local open-pollinated (OP) cultivars ('Bayrampaşa', 'Sakız') and five $F_{1}$ hybrid cultivars ('Olympus', 'Madrigal', 'Sambo', 'Green Globe', 'Imparator'), on the basis of total subcultures they were subjected to. Various plant growth regulators at various combinations were assessed for in vitro micropropagation and subsequent in vitro rooting. $3 / 4$ basic MS medium supplemented with $0.05 \mathrm{mg}$ $\mathrm{L}^{-1} \mathrm{BA}+0.005 \mathrm{mg} \mathrm{L}^{-1} \mathrm{IBA}$ was determined as the best media combination for in vitro micropropagation, while $10.0 \mathrm{mg} \mathrm{L}^{-1} \mathrm{IAA}+1.0 \mathrm{~g} \mathrm{~L}^{-1}$ activated charcoal adding to $1 / 2$ basic MS medium had positive effects on in vitro rooting. According to results, the micropropagation efficiency varied based on cultivar differences and number of subcultures regardless of being $\mathrm{OP}$ or $\mathrm{F}_{1}$ hybrid. The present study demonstrated that in vitro propagation of globe artichoke could be a valuable process for assessing mass propagation regardless of using $F_{1}$ or $O P$ cultivars. Considering the OP cultivars are cheap in terms of price in a comparison to $F_{1}$ hybrid cultivars, $O P$ cultivars could be also recommended to be used for in vitro mass propagation.
\end{abstract}

Keywords: globe artichoke; in vitro response; in vitro mass propagation; plant growth regulators; plant tissue culture

\section{Introduction}

Globe artichoke [Cynara cardunculus var. scolymus (L.) Fiori], which is an important crop and alternative medicine, has been grown intensely, especially in the Mediterranean basin countries. It has grown 
for its immature flowers (heads) has recently begun to be used in many fields, especially in pharmaceuticals, due to the high bioactive components of its body and leaves which are still being considered as waste material.

It can be produced both sexual and asexual. Sexual production is provided by seeds, asexual production refers to vegetative production. It is a cross-pollinated plant species and when propagated by seed, plants display high heterogeneity. Due to that it is generally not preferred for commercial production. Traditionally, vegetative propagation has become prominent (Bekheet et al., 2014). Offshoot or ovoli is used for vegetative propagation. However, vegetative propagation has some difficulties such as transferring some diseases and pests through the main plants used in the reproduction, the low reproduction rate during the growing period hinders genetic and agronomic development, physiological differences between shoots taken from the same parent plant and being less suitable for the mechanization (Ancora, 1986; Ordás et al., 1990; Morzadec and Hourmant, 1997; Rey et al., 2013; Saccardo et al., 2013; Bekheet et al., 2014; Campanelli et al., 2014; Dawa et al., 2018; Mazzeo et al., 2020).

In vitro methods help to overcome such problems and are seen as fast, reliable and realistic alternative methods that can be used for large scale production (Rey et al., 2013; Campanelli et al., 2014). Among these in vitro methods, the micropropagation technique was first developed in globe artichokes by De Leo and Greco (1973), and is a powerful alternative to traditional propagation. Homogenous, free from diseases and pests, healthy plants can be obtained by in vitro micropropagation method, while this method also provides a high reproduction rate. In previous micropropagation studies shoot tip, meristem and seeds were used as explants (Ancora et al., 1981; Pécaut et al., 1983; Rossi and De Paoli, 1992; El Boullani et al., 2012; Bekheet et al., 2014; Dawa et al., 2018). Due to the infection problem encountered in shoot tip culture, researchers decided to use meristem culture in order to obtain healthy, virus and other pathogens free plantlets. Different cultivars need different kind of incubation practices as well as different media combination and plant growth regulators. If all stated parameters are optimized, healthy plants can be obtained and the micropropagation rate can be increased. Plants obtained by in vitro micropropagation method perform well in terms of both qualitative and quantitative properties in cultivation and therefore compensate high in vitro production costs (Saccardo et al., 2007). In addition to all of these positive properties, it is important to provide an opportunity for the selection of plants with the high medical value among plants that are rapidly propagated in vitro.

Growers believe that the key to success requires combination of various approaches. Due to $F_{1}$ hybrids supplying a high degree of uniformity, disease resistance, and increased yield and "hybrid vigor", $\mathrm{F}_{1}$ hybrids are preferred by the majority of growers (Bonasia et al., 2010; Saccardo et al., 2013). On the other hand, it is also known that open-pollinated (OP) globe artichoke cultivars are prominent in some countries in the world as they are ideally adapted to certain environmental conditions. Due to the fact that OP's higher degree of genetic heterogeneity, they have high genetic diversity (Noorani et al., 2013; Mauromicale et al., 2018). Diminishing the possibility of disease or other genetic problems may help to protect from the environmental stresses. Additionally, it can be identified as a new trend that promoting some OP cultivars use among growers is encouraged by several governments in developing countries.

As stated above several in vitro studies were conducted on in vitro micropropagation of globe artichoke. To our knowledge, there is no study comparing the in vitro micropropagation responses of OP cultivars and $\mathrm{F}_{1}$ hybrids in globe artichoke. The present study was therefore conducted to reveal the in vitro micropropagation responses of 2 important local OP globe artichoke cultivars and 5 commercial $F_{1}$ hybrid globe artichoke cultivars. 


\section{Materials and Methods}

\section{Plant material}

In the present study, two important local OP globe artichoke cultivars, namely 'Bayrampaşa' and 'Sakız' and five $\mathrm{F}_{1}$ hybrid globe artichoke cultivars namely 'Olympus', 'Madrigal', 'Sambo', 'Green Globe' and 'Imparator' were used as plant materials.

\section{Culture preparation stage}

For the initiation of micropropagation, young shoots, about $10-15 \mathrm{~cm}$ size, were used as explant. The shoots collected from the experimental field were first washed under running tap water and soak in antibacterial soap for 10 minutes ( $900 \mathrm{~mL}$ of purified water $+100 \mathrm{~mL}$ of antibacterial soap). Subsequently, these plant materials were subjected to 2-stage surface sterilization in a laminar air flow workbench. In the initial surface sterilization process, the plant materials were treated with $40 \%$ (4.5\% sodium hypochlorite, $\mathrm{v} / \mathrm{v}$ ) commercial bleach solution for 15 minutes and then rinsed 3 times with sterile distilled water. After the first stage of surface sterilization, the plants' surface areas were reduced by cutting. Second surface sterilization stage was applied to these plant materials with $20 \%$ of commercial bleach solution ( $4.5 \%$ sodium hypochlorite, $v / v$ ) for 5 min and rinsed 3 times with sterile pure water. After successful 2-stage sterilization procedures, the meristems were separated from the main plant material by sterile forceps and scalpel and cultured in the medium prepared for micropropagation (Figure 1).

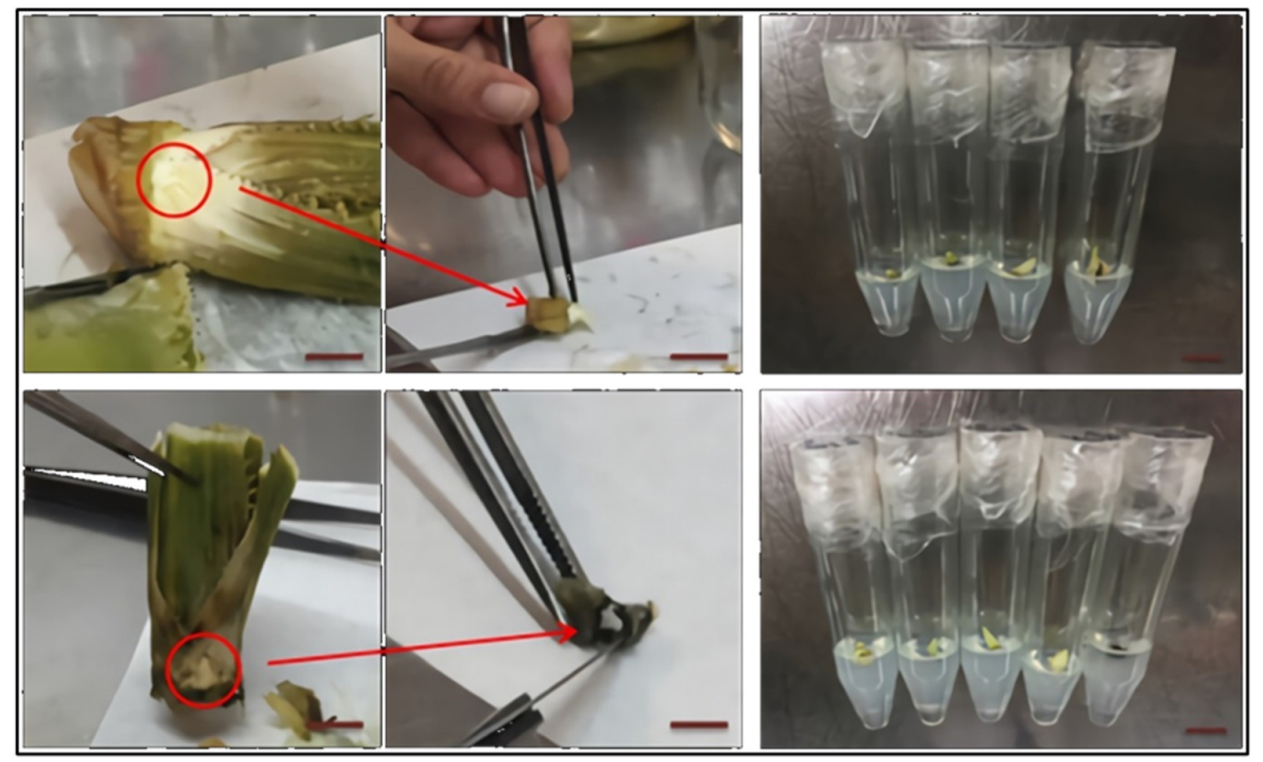

Figure 1. Separation of meristems from mother plant explants and culturing in micropropagation medium $(\mathrm{bar}=1.0 \mathrm{~cm})$

Murashige and Skoog (MS) (1962) was used as the basic medium for micropropagation. Two different media combinations were used in the study: $3 / 4 \mathrm{MS}$ medium was supplemented with $0.05 \mathrm{mg} \mathrm{L}^{-1} \mathrm{BA}+0.005 \mathrm{mg}$ $\mathrm{L}^{-1} \mathrm{IBA}$ (No.1) and $0.25 \mathrm{mg} \mathrm{L}^{-1} \mathrm{BA}+0.025 \mathrm{mg} \mathrm{L}^{-1} \mathrm{IBA}$ (No.2). These two media combinations were combined with sucrose $(3.0 \%)$ and agar $\left(6.0 \mathrm{~g} \mathrm{~L}^{-1}\right)$ and $\mathrm{pH}$ was adjusted to 5.8 before autoclaving.

\section{Meristem culture induction and axillary shoot proliferation}

The meristems were initially cultured in test tubes containing $10 \mathrm{~mL}$ of medium with one explant per tube (Figure 2). After 4 weeks, the shoots of the meristems were cut off to $1-3 \mathrm{~cm}$ length and transferred to 500 $\mathrm{mL}$ glass jars containing $100 \mathrm{~mL}$ medium. During subcultures, 5 explants were placed in each jar. Sub-culturing 
was repeated with 4 weeks intervals and continued until the $10^{\text {th }}$ subculture. Cultured plants were kept under $25 \pm 1^{\circ} \mathrm{C}$ and $16 / 8$ photoperiod conditions.

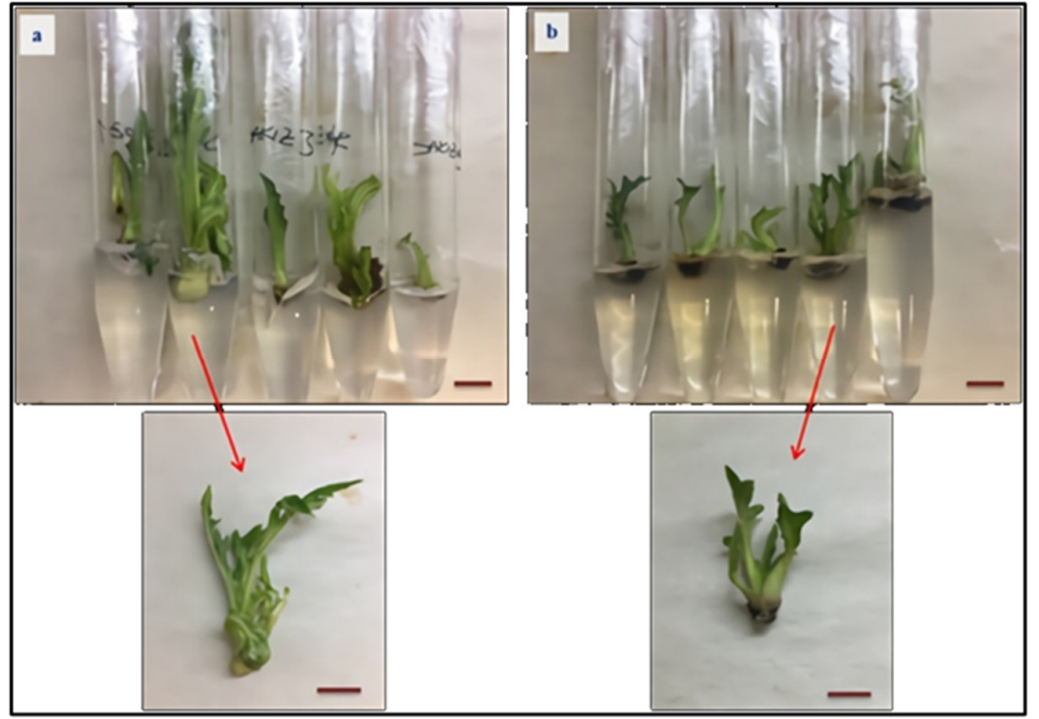

Figure 2. Observation of 1 month after the meristems was cultured; a. Sakı OP, b. Olympus $\mathrm{F}_{1}(\mathrm{bar}=1.0 \mathrm{~cm})$

\section{In vitro root induction and acclimatization}

For root induction, various media combinations were assessed. To serve the purpose, indole-3-acetic acid (IAA, $10.0 \mathrm{mg} \mathrm{L}^{-1}$ ), indole butyric acid (IBA, $6.0 \mathrm{mg} \mathrm{L}^{-1}$ ), gibberellic acid $\left(\mathrm{GA}_{3}, 5.0 \mathrm{mg} \mathrm{L}^{-1}\right.$ ), and naphthalene acetic acid (NAA, $0.5 \mathrm{mg} \mathrm{L}^{-1}$ ) were used at different concentrations and combinations with $1 / 2$ basic MS medium (Ozsan and Onus, 2019). The concentrations of plant growth regulators and activated charcoal (AC) doses $\left(1.0 \mathrm{~g} \mathrm{~L}^{-1}\right.$ and $\left.2.0 \mathrm{~g} \mathrm{~L}^{-1}\right)$ used in present study were based on previous studies (Ancora $e t$ al., 1981; Morzadec and Hourmant, 1997; Cavallaro et al., 2004; Tavazza et al., 2004; López-Pérez and Martínez, 2015; Ercan, 2016).

While the micropropagation was in progress, the acclimatization of in vitro rooted plantlets to the in vivo conditions was also carried out. For this purpose, in vitro rooted plantlets (Figure 3) were transplanted into plastic trays containing peat: perlite (1:1) mixture. Plastic trays were covered with polyethylene cover during 10 days. The plantlets were watered twice a day. During 30-40 days of acclimatization process observations were made on plantlets and at the end acclimatization period surviving plants were transferred to the field.

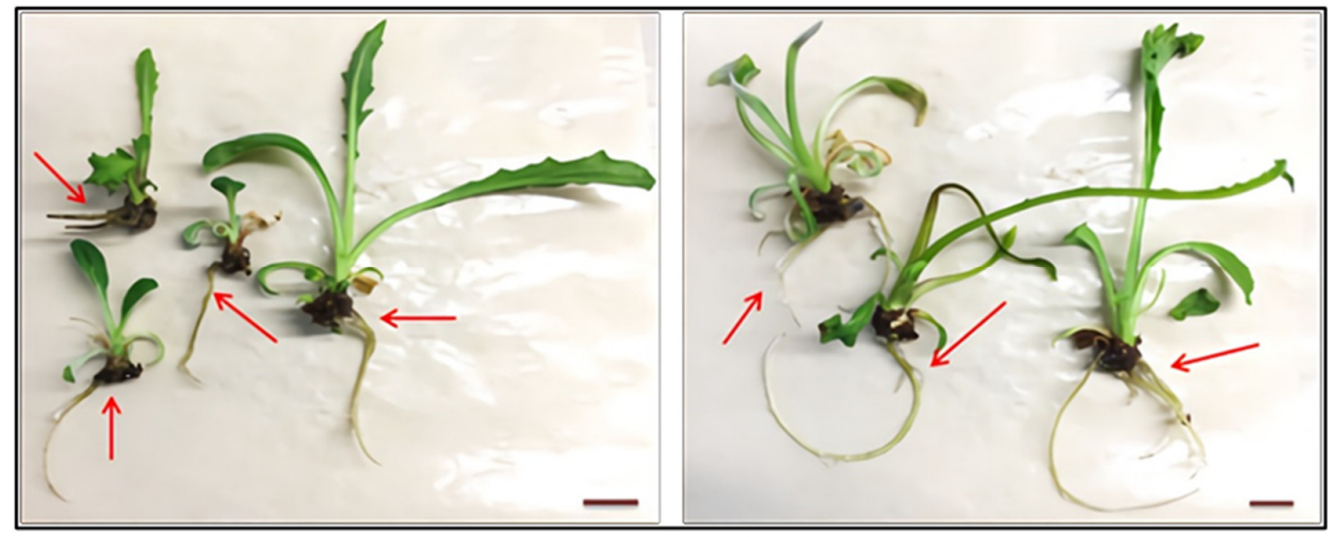

Figure 3. Rooted plantlets belonging to Sakız OP cultivar $(\mathrm{bar}=1.0 \mathrm{~cm})$ 


\section{Evaluated parameters}

In vitro micropropagation rates, the average number of axillary shoots per explant, the average number of leaves per axillary shoot, in vitro root formation and respond to acclimatization were compared on the basis of being OP and $F_{1}$ hybrid globe artichoke cultivars. Since each subculture was carried out with 4 weeks intervals, the number of new shoots was counted to calculate multiplication rate (MR) at the end of 4 weeks.

\section{Statistical analysis}

The experiment was performed in three replications for comparing 2 OP globe artichoke cultivars and $5 \mathrm{~F}_{1}$ hybrid globe artichoke cultivars to analyze their in vitro micropropagation response. Three jars were used in each replicate and 5 explants were used in each jar. The data obtained were subjected to variance analysis in the JMP package program and the differences between the averages were determined by LSD test.

\section{Results and Discussion}

\section{Disinfection protocol}

Globe artichoke can be propagated via in vitro methods or traditional methods by using offshoots. In a comparison between in vitro propagation and traditional propagation methods, in vitro propagation has several advantages such as high multiplication rate and obtaining disease free starting material. But in vitro multiplication methods have its own disadvantages, too i.e. infection; shoot hyperhydricity and browning (Alp et al., 2010).

This is why the plant materials were subjected to 2-stage surface sterilization. The initial disinfection stage was carried out with high concentration commercial bleach to remove soil-based infection/contamination sources. After the $1^{\text {st }}$ stage, the plant materials were trimmed down to make them ready for $2^{\text {nd }}$ stage disinfection process in order to prevent further infection/contamination. Since the results obtained from present study are highly positive regarding disinfection, 2-stage surface sterilization can be recommended for future studies.

\section{Evaluations of media combinations}

The micropropagation was conducted with two media combinations until $3^{\text {rd }}$ subculture. In previous studies, it was stated that MS basic medium supports in vitro shoot formation in globe artichoke (De Leo and Greco, 1973; Ancora et al., 1981; Pécaut et al., 1983; Iapichino, 1996; Alp et al., 2010; El-Zeiny et al., 2013; López-Pérez and Martínez, 2015; Dawa et al., 2018). Throughout the experiments, media combinations were carried out with MS basic medium and it was found that MS basic media supplemented with $0.05 \mathrm{mg} \mathrm{L}^{-1} \mathrm{BA}$ $+0.005 \mathrm{mg} \mathrm{L}^{-1}$ IBA combination (No.1) was more successful than media combination of $0.25 \mathrm{mg} \mathrm{L}^{-1} \mathrm{BA}+$ $0.025 \mathrm{mg} \mathrm{L}^{-1} \mathrm{IBA}$ (No.2) in terms of general appearance, growth and development of plantlets. It is why all the plantlets originating from media combination No.2 were discarded and plantlets coming from media combination No.1 were used for the rest of the experiment period. Results on media evaluation clearly showed that medium No.1 was superior over medium No.2. In other words, lower concentrations of BA and IBA resulted with good growth and development of in vitro plantlets of the all globe artichoke cultivars used. Similar findings were also reported in previous studies. In a study conducted by Bedini et al. (2012), they reported that combination of BA and IBA at reduced concentrations was very successful for in vitro propagation of globe artichoke. Several studies also reported that the use of low plant growth regulators concentrations promoted and enhanced the plantlet quality (Ancora et al., 1981; Pécaut et al., 1983; Rossi and De Paoli, 1992; Morone Fortunato and Ruta, 2003; Castiglione et al., 2007; Bedini et al., 2012). It is assumed that increasing plant growth regulator concentration stimulate negative symptoms such as browning and shoot hyperhydricity (Rossi and De Paoli, 1992; Brutti et al., 2000; Pacifici et al., 2007; Bedini et al., 2012). So, findings of the present study are in accordance with previous studies. 


\section{Multiplication rates (MR)}

There was no rapid increase in MR at the beginning of culture for $\mathrm{OP}$ and $\mathrm{F}_{1}$ hybrid globe artichoke cultivars. As the number of subcultures increased, the shoots became well adapted to in vitro conditions and MR, therefore, increased (Table 1). Many researchers think that low MR at the beginning of culture is associated with the initial stress of shoots and as a result of getting adapted to in vitro conditions in due time either MR increases or inter subcultural fluctuations are minimized (Phillips et al., 1994; Zucchi et al., 2002; Rey et al., 2013). Findings of present study about MR are, thus, in agreement with previous studies. MR showed variation based on cultivar being OP or $\mathrm{F}_{1}$ hybrid and as well as number of subcultures. 'Bayrampaşa' OP globe artichoke cultivar and 'Madrigal' and 'Imparator' $F_{1}$ hybrid globe artichoke cultivars reached the maximum MR at the $10^{\text {th }}$ subculture. On the other hand, 'Green Globe' and 'Sambo' $F_{1}$ hybrid globe artichoke cultivars were reached to maximum MR at the $8^{\text {th }}$ subculture, while 'Sakı' OP globe artichoke cultivar and 'Olympus' $\mathrm{F}_{1}$ hybrid globe artichoke cultivar reached to maximum MR at the $6^{\text {th }}$ subculture. Although the 'Bayrampaşa' $\mathrm{OP}$ and 'Imparator' $F_{1}$ hybrid globe artichoke cultivars reached the maximum $M R$ in the $10^{\text {th }}$ subculture, these values were found to be the highest $M R$ values when the overall study was evaluated. Although, Madrigal $F_{1}$ hybrid cultivar reached the maximum MR in the $10^{\text {th }}$ subculture like these cultivars, the MR of 'Bayrampaşa $\mathrm{OP}$ and 'Imparator' $F_{1}$ hybrid globe artichoke cultivars were about 5 times higher than 'Madrigal' $F_{1}$ hybrid cultivar. Although, 'Sakız' OP cultivar reached the maximum MR in the $6^{\text {th }}$ subculture there were fluctuations between the $7^{\text {th }}$ and $10^{\text {th }}$ subcultures. The most fluctuations on MR values were recorded in $F_{1}$ hybrid cultivars, 'Madrigal', 'Sambo' and 'Green Globe'. In previous studies, it was revealed that there was a relationship between the number of subcultures and in vitro proliferation. El-Zeiny et al. (2013) reported that they recorded an increase in in vitro production until the $5^{\text {th }}$ subculture in a total of 7 subcultures conducted in their study. Similarly, Dawa et al. (2018) stated that when the number of subcultures was increased in vitro multiplication rate also increased until a certain number of subcultures. It is thought that decision of how many subcultures needed to reach to certain number of plants should be done heavily depends on the cultivars used for in vitro micropropagation.

Table 1. Multiplication rates/subculture based on cultivars (\%)

\begin{tabular}{|c|c|c|c|c|c|c|c|}
\hline \multicolumn{8}{|c|}{ Cultivars } \\
\hline $\begin{array}{l}\text { No of sub- } \\
\text { culture }\end{array}$ & $\begin{array}{c}\text { 'Bayrampaşa' } \\
\text { OP }\end{array}$ & $\begin{array}{c}\text { 'Sakız' } \\
\text { OP }\end{array}$ & $\begin{array}{c}\text { 'Olympus' } \\
F_{1} \\
\end{array}$ & $\begin{array}{c}\text { 'Madrigal' } \\
F_{1} \\
\end{array}$ & $\begin{array}{c}\text { Sambo' } \\
\mathrm{F}_{1}\end{array}$ & $\begin{array}{c}\text { 'Green } \\
\text { Globe' } F_{1}\end{array}$ & $\begin{array}{c}\text { 'Imparator' } \\
\mathrm{F}_{1} \\
\end{array}$ \\
\hline 0 & $3.00 \mathrm{p}-\mathrm{u}$ & $1.33 \mathrm{uv}$ & 1.66 tuv & $4.33 n-t$ & $4.66 \mathrm{~m}-\mathrm{s}$ & $5.331-p$ & $6.66 \mathrm{j}-\mathrm{n}$ \\
\hline 1 & $4.33 n-t$ & $3.33 \mathrm{o}-\mathrm{u}$ & 1.66 tuv & $3.00 \mathrm{p}-\mathrm{u}$ & $3.00 \mathrm{p}-\mathrm{u}$ & $2.33 \mathrm{r}-\mathrm{v}$ & $5.001-\mathrm{r}$ \\
\hline 2 & $7.66 \mathrm{jkl}$ & $6.00 \mathrm{k}-\mathrm{o}$ & $2.00 \mathrm{~s}-\mathrm{v}$ & $2.33 \mathrm{r}-\mathrm{v}$ & $1.33 \mathrm{uv}$ & $3.66 \mathrm{o}-\mathrm{u}$ & $9.00 \mathrm{hij}$ \\
\hline 3 & $28.00 \mathrm{e}$ & $25.33 \mathrm{e}$ & $7.33 \mathrm{j}-\mathrm{m}$ & $3.33 \mathrm{o}-\mathrm{u}$ & 1.66 tuv & $8.33 \mathrm{ijk}$ & $33.33 \mathrm{~d}$ \\
\hline 4 & $76.00 \mathrm{w}$ & $86.00 \mathrm{v}$ & $26.33 \mathrm{e}$ & $6.66 j-n$ & $1.00 \mathrm{uv}$ & $33.66 \mathrm{~d}$ & $76.00 \mathrm{w}$ \\
\hline 5 & 199.66 o & 256.001 & $75.00 \mathrm{w}$ & 10.66 ghi & $11.33 \mathrm{gh}$ & $61.00 \mathrm{z}$ & $94.66 \mathrm{u}$ \\
\hline 6 & $457.00 \mathrm{f}$ & $512.66 \mathrm{e}$ & $226.66 n$ & $21.00 \mathrm{f}$ & $12.00 \mathrm{~g}$ & $38.00 \mathrm{c}$ & $154.66 \mathrm{p}$ \\
\hline 7 & $652.66 \mathrm{~d}$ & $312.00 \mathrm{j}$ & $144.00 \mathrm{q}$ & $44.00 \mathrm{~b}$ & $85.00 \mathrm{v}$ & $35.66 \mathrm{~cd}$ & $230.33 \mathrm{~m}$ \\
\hline 8 & $697.66 \mathrm{c}$ & $300.00 \mathrm{k}$ & $111.66 \mathrm{st}$ & $109.33 \mathrm{t}$ & $113.33 \mathrm{~s}$ & $62.00 \mathrm{yz}$ & $421.33 \mathrm{~h}$ \\
\hline 9 & $700.00 \mathrm{bc}$ & 256.001 & $146.00 \mathrm{q}$ & $65.00 x$ & $64.00 \mathrm{xy}$ & $22.00 \mathrm{f}$ & $442.66 \mathrm{~g}$ \\
\hline 10 & $700.66 \mathrm{~b}$ & 345.001 & $84.33 \mathrm{v}$ & $134.00 \mathrm{r}$ & $56.33 \mathrm{a}$ & $0 \mathrm{v}$ & $709.66 \mathrm{a}$ \\
\hline $\begin{array}{c}\text { Averages of } \\
\text { cultivars }\end{array}$ & $320.60 \mathrm{~A}$ & $191.24 \mathrm{~B}$ & $75.15 \mathrm{C}$ & $36.69 \mathrm{C}$ & $32.15 \mathrm{C}$ & $24.72 \mathrm{C}$ & $198.48 \mathrm{~B}$ \\
\hline LSD values & \multicolumn{7}{|c|}{ LSD cultivar $^{*}=11.78 \quad$ LSD subculture ${ }^{*}=14.08$} \\
\hline
\end{tabular}




\section{Axillary shoots formation}

There was no statistically significant difference, in terms of average axillary shoots formation, among cultivars regardless of being $\mathrm{OP}$ or $\mathrm{F}_{1}$. On the other hand, there were statistically significant differences among all cultivars regarding axillary shoots formation based on number of subculture (Table 2). Among all evaluated globe artichoke cultivars, 'Imparator' $F_{1}$ hybrid had with 12.33 axillary shoots/explant at $7^{\text {th }}$ subculture. Considering the response of $\mathrm{OP}$ and $\mathrm{F}_{1}$ hybrid cultivars to subculture averages, the $\mathrm{OP}$ cultivars demonstrated consistent values between each other with respect to axillary shoot formation in different subcultures, while $F_{1}$ hybrid cultivars had fluctuations on axillary shoot formation. 'Green Globe' $F_{1}$ demonstrated the lowest axillary shoot formation at the $10^{\text {th }}$ subculture due to heavy infection problem.

Table 2. Average axillary shoot formation/explant based on cultivars

\begin{tabular}{|c|c|c|c|c|c|c|c|}
\hline \multicolumn{8}{|c|}{ Cultivars } \\
\hline $\begin{array}{l}\text { No of sub- } \\
\text { culture }\end{array}$ & $\begin{array}{c}\text { 'Bayrampaşa' } \\
\text { OP }\end{array}$ & $\begin{array}{l}\text { 'Sakı' } \\
\text { OP }\end{array}$ & $\begin{array}{c}\text { 'Olympus' } \\
\mathrm{F}_{1}\end{array}$ & $\begin{array}{c}\text { 'Madrigal' } \\
\mathrm{F}_{1}\end{array}$ & $\begin{array}{c}\text { 'Sambo' } \\
F_{1}\end{array}$ & $\begin{array}{c}\text { 'Green } \\
\text { Globe’ } F_{1}\end{array}$ & $\begin{array}{c}\text { 'Imparator' } \\
\mathrm{F}_{1}\end{array}$ \\
\hline 0 & $1.00 \mathrm{n}$ & $1.00 \mathrm{n}$ & $1.00 \mathrm{n}$ & $1.00 \mathrm{n}$ & $1.00 \mathrm{n}$ & $1.00 \mathrm{n}$ & $1.00 \mathrm{n}$ \\
\hline 1 & $2.15 \mathrm{~h}$ & $2.50 \mathrm{f}$ & $1.00 \mathrm{n}$ & $1.31 \mathrm{~m}$ & $1.82 \mathrm{j}$ & 1.571 & $2.14 \mathrm{~h}$ \\
\hline 2 & $3.28 \mathrm{~d}$ & $3.00 \mathrm{e}$ & $2.00 \mathrm{i}$ & $2.32 \mathrm{~g}$ & $1.33 \mathrm{~m}$ & $1.83 \mathrm{j}$ & $4.51 \mathrm{wx}$ \\
\hline 3 & $4.94 \mathrm{t}$ & $4.47 x y$ & $4.41 \mathrm{yz}$ & $3.37 \mathrm{c}$ & $1.66 \mathrm{k}$ & $3.72 \mathrm{~b}$ & $5.26 \mathrm{q}$ \\
\hline 4 & $4.65 \mathrm{v}$ & $5.26 \mathrm{q}$ & $5.64 n$ & $5.03 \mathrm{rs}$ & $1.97 \mathrm{i}$ & 5.931 & $4.37 \mathrm{z}$ \\
\hline 5 & $4.95 \mathrm{t}$ & $7.33 \mathrm{c}$ & $7.50 \mathrm{~b}$ & $4.57 \mathrm{w}$ & $4.84 \mathrm{u}$ & $7.32 \mathrm{c}$ & $4.64 \mathrm{v}$ \\
\hline 6 & $6.23 \mathrm{i}$ & $6.32 \mathrm{~h}$ & $6.80 \mathrm{f}$ & $4.93 \mathrm{t}$ & $4.01 \mathrm{a}$ & $6.79 \mathrm{f}$ & $6.16 j$ \\
\hline 7 & $5.36 \mathrm{p}$ & $6.16 j$ & $5.83 \mathrm{~m}$ & $5.36 \mathrm{p}$ & $5.67 n$ & $6.27 \mathrm{hi}$ & $12.33 \mathrm{a}$ \\
\hline 8 & $4.94 \mathrm{t}$ & $5.68 n$ & $7.13 \mathrm{~d}$ & $5.67 n$ & $6.74 \mathrm{f}$ & $6.64 \mathrm{~g}$ & $4.98 \mathrm{st}$ \\
\hline 9 & $5.06 \mathrm{r}$ & $6.04 \mathrm{k}$ & $6.95 \mathrm{e}$ & $6.79 \mathrm{f}$ & $5.48 \mathrm{o}$ & $5.51 \mathrm{o}$ & $4.92 \mathrm{t}$ \\
\hline 10 & $5.10 \mathrm{r}$ & $4.46 \mathrm{xy}$ & $4.44 \mathrm{yz}$ & $6.28 \mathrm{hi}$ & $6.03 \mathrm{k}$ & $0 \mathrm{o}$ & $4.98 \mathrm{st}$ \\
\hline $\begin{array}{l}\text { Averages of } \\
\text { cultivars }\end{array}$ & 4.33 & 4.74 & 4.79 & 4.24 & 3.68 & 4.23 & 5.02 \\
\hline LSD values & \multicolumn{2}{|c|}{ LSD cultivar $*=0.26$} & LSD subcu & $\mathrm{re}^{*}=0.31$ & \multicolumn{3}{|c|}{ LSD cultivar $\mathrm{x}$ subculture ${ }^{*}=0.82$} \\
\hline
\end{tabular}

Different letters between cultivars denote statistically significant differences (LSD test, $\mathrm{p}<0.05$ )

Each cultivar belonging to OP or $\mathrm{F}_{1}$ hybrids demonstrated variation in itself. It is clearly demonstrated that applying a certain number of subcultures is a necessity to obtain certain number of in vitro plants, regardless of being OP or $\mathrm{F}_{1}$ hybrid cultivar. Bedini et al. (2012) stated that maximum shoot proliferation was obtained after $3^{\text {rd }}$ subculture. Similar reports were also reported by Pacifici et al. (2007). Findings of present and previous studies clearly indicated that globe artichoke's proliferative process and number of needed subcultures depends on cultivars.

\section{Leaf formation}

When the average number of leaves formed on the explant of the globe artichoke cultivars was evaluated, it was seen that OP cultivars had more positive results; especially 'Sakız' formed the maximum average with 20.8 leaves/explant. When leaf formation considered, the OP cultivars reached to maximum leaf formation/explant at the $5^{\text {th }}$ subculture. It was clearly seen that each $F_{1}$ hybrid cultivar predominantly reached to maximum leaf formation/explant at the $4^{\text {th }}$ subculture although two of them reached at $5^{\text {th }}$ and $8^{\text {th }}$ subcultures. According to Pacifici et al. (2007), the increase in the number of leaves formed in in vitro conditions will cause more water loss and cause difficulties in the adaptation of artichoke plants to in vivo conditions. Many previous studies demonstrated that leaves of in vitro plants have different morphological structures in a comparison to in vivo leaves. Accordingly, since they have different leaf morphology, in vitro plants need to adapt themselves to unfavorable environmental conditions of in vivo by changes on morphological, anatomical, and physiological features (Brutti et al., 2000; Cavallaro et al., 2007). 
Table 3. Average leaf formation/explant based on cultivars

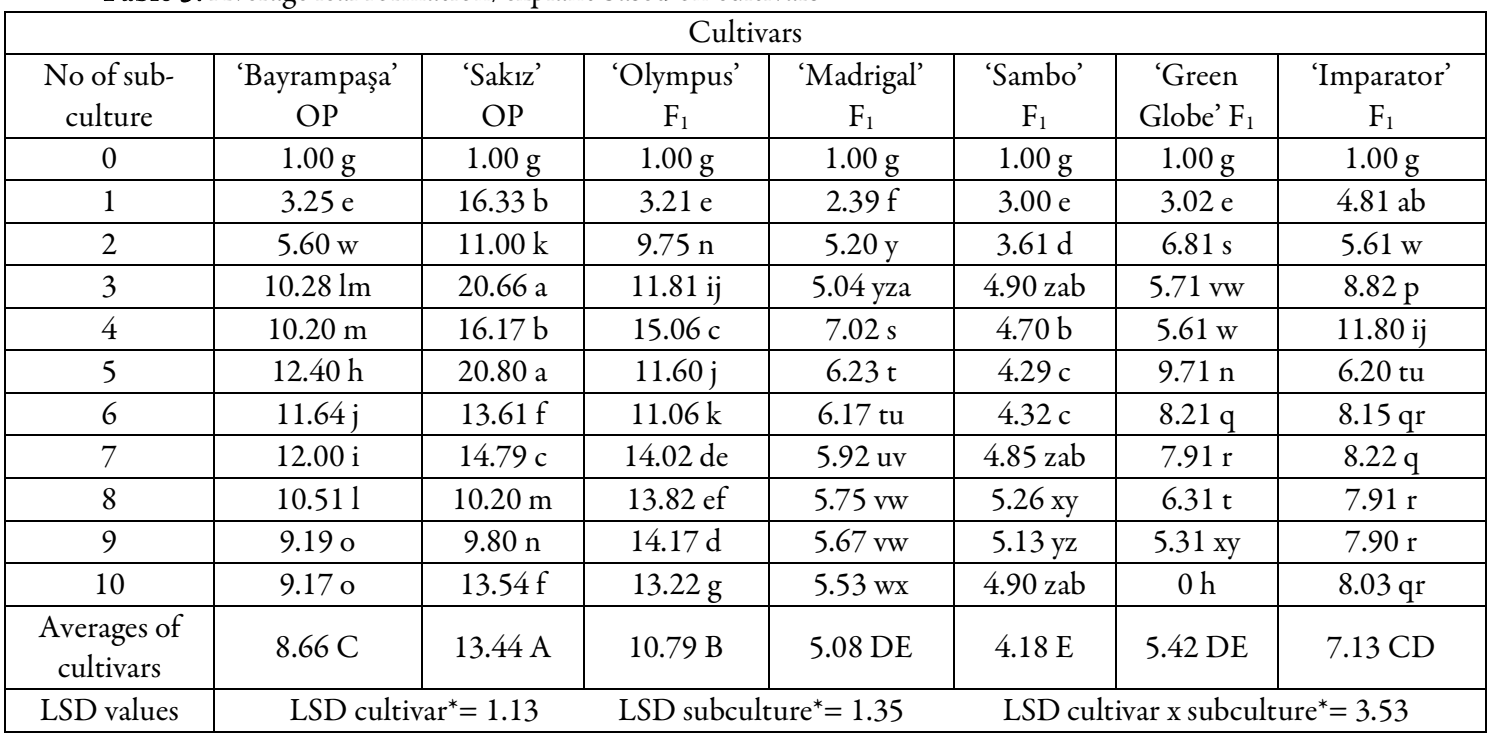

Different letters between cultivars denote statistically significant differences (LSD test, $\mathrm{p}<0.05$ )

\section{Evaluation of in vitro rooting, acclimatization and survival percentages of cultivars}

In this study, the rooting success of the plantlets after micropropagation stage was also evaluated (Table 4). To achieve well-formed root formation several media combinations were tested. Among rooting media combinations $1 / 2 \mathrm{MS}$ medium combined with $10.0 \mathrm{mg} \mathrm{L}^{-1} \mathrm{IAA}+1.0 \mathrm{~g} \mathrm{~L}^{-1}$ activated charcoal was determined to have positive results in terms of in vitro rooting. Although some of the plantlets all of cultivars obtained between $6^{\text {th }}$ and $9^{\text {th }}$ subcultures in the medium used for micropropagation were rooted, their rooting percentages were not enough, so they were not taken into further consideration. Regarding in vitro rooting percentage, 'Sakız' OP cultivar was the best, while 'Sambo' $F_{1}$ hybrid cultivar had the lowest rooting. At the acclimatization stage it was obvious that $\mathrm{F}_{1}$ hybrid globe artichoke cultivars adapted to in vivoconditions better than OP globe artichoke cultivars. Obtained results clearly revealed that right media combination is a necessity for well root formation and right media combination may vary based on genotype. Similar findings were also reported by Cavallaro et al. (2004); Iapichino (2013); López-Pérez and Martínez (2015). As stated in previous studies, the most challenging part of in vitro micropropagation studies for globe artichoke is the in vitro rooting stage (López-Pérez and Martínez, 2015; Ercan, 2016). As seen in present study, in vitro rooting rate is quite low due to genotype-related differences. This is a limiting step for the micropropagation, suggesting that various optimization studies are still needed for in vitro rooting (López-Pérez and Martínez, 2015).

In the present study, the acclimatized plant percentages were found to be rather low. In a previous study conducted by Cavallaro et al. (2007), it was found that there was a relationship between acclimatization time and acclimatized plants. Researchers revealed that the most favorable percentage of acclimatized plants was obtained in the September plantation time due to thermal conditions. On the other hand, in the current study, the plantation was performed in March. Thus, it is thought that having low level of the acclimatized plant percentages can be attributed to unfavorable thermal conditions in March. 
Table 4. In vitro rooting, acclimatization and survived plantlets of artichoke cultivars

\begin{tabular}{|c|c|c|c|}
\hline Cultivars & $\begin{array}{c}\text { Percentages of in vitro } \\
\text { rooting }(\%)\end{array}$ & $\begin{array}{c}\text { Percentages of acclimatization } \\
(\%)\end{array}$ & $\begin{array}{c}\text { Percentages of survived } \\
\text { plantlets }(\%)\end{array}$ \\
\hline 'Bayrampaşa' OP & $5.35 \mathrm{~b}$ & $81.14 \mathrm{c}$ & $8.86 \mathrm{bc}$ \\
\hline 'Sakız' OP & $6.47 \mathrm{a}$ & $88.80 \mathrm{~b}$ & $7.54 \mathrm{c}$ \\
\hline 'Olympus' $F_{1}$ & $1.80 \mathrm{e}$ & $88.38 \mathrm{~b}$ & $10.00 \mathrm{~b}$ \\
\hline 'Madrigal' $F_{1}$ & $4.02 \mathrm{c}$ & $100.00 \mathrm{a}$ & $10.37 \mathrm{~b}$ \\
\hline 'Sambo' $F_{1}$ & $0.73 \mathrm{f}$ & $100.00 \mathrm{a}$ & $0 \mathrm{~d}$ \\
\hline 'Green Globe' F & $2.32 \mathrm{~d}$ & $100.00 \mathrm{a}$ & $0 \mathrm{~d}$ \\
\hline 'Imparator' $F_{1}$ & $2.24 \mathrm{~d}$ & $73.78 \mathrm{~d}$ & $12.87 \mathrm{a}$ \\
\hline LSD values & \multicolumn{3}{|c|}{ LSD in vitro rooting ${ }^{*}=2.013 ;$ LSD acclimatization ${ }^{*}=17.19 ;$ LSD survived plantlets ${ }^{*}=44.81$} \\
\hline
\end{tabular}

Different letters between cultivars denote statistically significant differences (LSD test, $\mathrm{p}<0.05$ )

\section{Conclusions}

The present study was aimed to comparatively evaluate in vitro micropropagation efficiency of 2 important local OP globe artichoke cultivars ('Bayrampaşa', 'Sakız') and $5 \mathrm{~F}_{1}$ hybrid globe artichoke cultivars ('Olympus', 'Madrigal', 'Sambo', 'Green Globe' and 'Imparator'). The experimental results clearly revealed that $\mathrm{OP}$ cultivars and $\mathrm{F}_{1}$ hybrid cultivars reacted differently to in vitro mass micropropagation. Besides genotypic differences, it was also observed the number of subcultures was one of the essential factors that affect in vitro multiplication rates in both $\mathrm{OP}$ and $\mathrm{F}_{1}$ hybrids. Although the $\mathrm{F}_{1}$ hybrid cultivars were ahead of the OP cultivars at the acclimation stage, the multiplication rates and rooting values of the OPs were found almost similar to $F_{1}$ hybrid cultivars. Therefore, if there are local OP cultivars well adapted to certain ecological conditions as well as having good yield and fruit quality, they can be used in in vitro mass propagation as an alternative to $F_{1}$ hybrid cultivars which are expensive and sometimes not easy to find.

\section{Authors' Contributions}

Both authors read and approved the final manuscript.

\section{Acknowledgements}

The present study was partly funded by Akdeniz University Scientific Research Projects Coordination Unit with the project numbers FDK-2019-4611 and FBA-2019-4814. Thanks to Dr. Mehmet Ali Saridas from Cukurova University for his contribution to statistical analysis.

\section{Conflict of Interests}

The authors declare that there are no conflicts of interest related to this article. 


\section{References}

Alp HA, Düzyaman E, Özzambak E (2010). İn Vitro’da Kültüre Alınan Enginar Sürgün Uçlarında Sağlıklı Gelişim Oranını Arttırma Olanakları Üzerinde Bir Araştırma. Ege Üniversitesi Ziraat Fakültesi Dergisi 47(2):113-122.

Ancora G (1986). Globe artichoke (Cynara scolymus L.). In: Bajaj YPS (Ed). Biotechnology in agriculture and forestry Vol 2. Crops I. Springer, Berlin Heidelberg New York pp 471-483.

Ancora G, Belli-Donini ML, Cuozzo L (1981). Globe artichoke plants obtained from shoot apices through rapid in vitro micropropagation. Scientia Horticulturae 14:207-213. https://doi.org/10.1016/0304-4238(81)90014-5

Bedini L, Lucchesini M, Bertozzi F, Graifenberg A (2012). Plant Tissue cultures from four tuscan globe artichoke cultivars. Central European Journal of Biology 7:680-689 http://dx.doi.org/10.2478/s11535-012-0064-X

Bekheet SA, Gabr AMM, El-Bahr MK (2014). Development a protocol for in vitro morphogenesis and multiplication of globe artichoke (Cynara scolymus L). International Journal of Academic Research Part A http://dx.doi.org/10.7813/2075-4124.2014/6-6/A.41

Bonasia A, Conversa G, Lazzizera C, Gambacorta G, Elia A (2010) Morphological and qualitative characterisation of globe artichoke head from new seed-propagated cultivars. Journal of the Science of Food and Agriculture 90:2689-2693. https://doi.org/10.1002/jsfa.4141

Brutti C, Apostolo NM, Ferrarotti SA, LLOrente BE, Krymkiewicz N (2000). Micropropagation of Cynara scolymus L. employing cyclodestrins to promote rhizogenesis. Scientia Horticulturae 83(1):1-10. https://doi.org/10.1016/S0304-4238(99)00067-9

Campanelli A, Ruta C, Tagarelli A, Morone Fortunato I, De Mastro G (2014). Effectiveness of mycorrhizal fungi on globe artichoke (Cynara cardunculus L. var. scolymus) micropropagation. Journal of Plant Interactions http://dx.doi.org/10.1080/17429145.2013.770928

Castiglione V, Cavallaro V, Di Silvestro I, Melilli MG (2007). Influence of different substrates on in vitro initiation of some early and late cultivars of globe artichoke [Cynara cardunculus L. subsp. scolymus (L.) Hayek]. Acta Horticulturae 730:107-112.

Cavallaro V, Castiglione V, Avola G, Finocchiaro E (2004). Influence of different substrates on the in vitro rhizogenesis process of early artichoke [Cynara cardunculus L. subsp. scolymus (L.) Heg]. Acta Horticulturae 660:267-272.

Cavallaro V, Castiglione V, Di Silvestro I, Patanè C, Barbera AC (2007). Influence of different transplant times and mycorrhizal symbiosis on the acclimatisation process of micropropagated artichoke [Cynara cardunculus $\mathrm{L}$. subsp. scolymus (L.) Hayek]. Acta Horticulturae 730:75-80.

Dawa, KK, El-Saady W M, El-Denary ME, Abo-Elglagel IM (2018). In vitro micropropagation of globe artichoke plant (Cynara scolymus L.): 1- effect of sodium hypochlorite concentrations, cytokinins and subcultures number on shoots multiplication rate. Journal of Plant Production 3(7):1-13. http://dx.doi.org/10.21608/jpp.2012.84897

De Leo P, Greco B (1973). New technique of propagation of the artichoke: in vitro culture of apical meristems. In: Proceedings of the Third International Congress on Artichoke, Bari, Italy pp 657-665.

El Boullani R, Elmoslih A, El Finti A, El Mousadik A, Serghini MA (2012). Improved in vitro micropropagation of artichoke (Cynara cardunculus var. scolymus L.). European Journal of Scientific Research 80(4):430-436.

El-Zeiny OAH, El-Behairy UA, Zocchi G, Rashwan MM (2013). Commercial production of globe artichoke (Cynara scolymus L.) in vitro. Egyptian Journal of Agricultural Research 91(3):993-1007.

Ercan N (2016). Effects of various growth regulators on in vitro rooting of globe artichoke (Cynara scolymus L.). Journal of Agricultural Science and Technology 6:335-340. http://dx.doi.org/10.17265/2161-6256/2016.05.005

Iapichino G (1996). Micropropagation of globe artichoke (Cynara scolymus L.) from underground dormant buds ("Ovoli"). In Vitro Cellular \& Developmental Biology - Plant 32:249-252. https://doi.org/10.1007/BF02822695

Iapichino G (2013). Micropropagation of globe artichoke (Cynara cardunculus L. var. scolymus). In: Lambardi M et al. (Eds.). Protocols for micropropagation of selected economically-1mportant horticultural plants, methods in molecular biology. Springer Science+Business Media New York pp 369-380.

López-Pérez AJ, Martínez JA (2015). In vitro root induction improvement by culture in darkness for different globe artichoke cultivars. In Vitro Cellular \& Developmental Biology - Plant http://dx.doi.org/10.1007/s11627-0159667-z

Mauromicale G, Portis E, Acquadro A, Lo Monaco A, Pesce GR, Lanteri S (2018). An integrated model to accelerate the development of seed-propagated varieties of globe artichoke. Crop Breeding and Applied Biotechnology 18:7280. http://dx.doi.org/10.1590/1984-70332018v18n1a10 
Mazzeo G, Scavo A, Lo Monaco A, Longo S, Mauromicale G (2020). Insect pollinators improve seed production in globe artichoke (Cynara cardunculus var. scolymus). Annals of Applied Biology 176:241-248. https://doi.org/10.1111/aab.12570

Morone Fortunato I, Ruta C (2003). Micropropagated artichoke plants with early inoculation of arbuscular mycorrhizal fungi. Italus Hortus 10:213-218 (in Italian).

Morzadec JM, Hourmant A (1997). In vitro rooting improvement of globe artichoke (cv. Camus de Bretagne) by $\mathrm{GA}_{3}$. Scientia Horticulturae 72(1):59-62. https://doi.org/10.1016/S0304-4238(97)00112-X

Murashige T, Skoog F (1962). A revised medium for rapid growth and bioassays with tobacco tissue culture. Physiologia Plantarum 15:473-497. https://doi.org/10.1111/j.1399-3054.1962.tb08052.x

Noorani A, Rey NA, Mondini L, Ciancolini A, Crinò P, Pagnotta MA (2013). Morphological diversity assessment in wild and cultivated cardoons. Acta Horticuturae 983:47-54. https://doi.org/10.17660/ActaHortic.2013.983.4

Ordás RJ, Tavazza R, Ancora G (1990). In vitro morphogenesis in the globe artichoke (Cynara scolymus L.). Plant Science 71(2):223-237. https://doi.org/10.1016/0168-9452(90)90013-E

Ozsan T, Onus AN (2019). A protocol on in vitro rooting of 'Bayrampaşa' artichoke (Cynara scolymus L.). Mediterranean Agricultural Sciences 32(2):1-6. https://doi.org/10.29136/mediterranean.559194

Pacifici S, Lucchesini M, Curadi M, Grainfenberg A (2007). Influence of medium composition and vessel ventilation during the micropropagation stages of Cynara scolymus L. cv. Grato 1. Advances in Horticultural Science 21:8388.

Pécaut P, Dumas de Vaulx R, Lof H (1983). Virus-free clones of globe artichoke (Cynara scolymus, L.) obtained after in vitro propagation. Acta Horticulturae 131:303-309. https://doi.org/10.17660/ActaHortic.1983.131.36

Phillips RL, Kaeppler SM, Olhoft P (1994). Genetic instability of plant tissue cultures: breakdown of normal controls. Proceedings of the National Academy of Sciences of the United States of America 91(12):5222-5226. https://doi.org/10.1073/pnas.91.12.5222

Rey NA, Papacchioli V, Tavazza R, Pagnotta MA (2013). Gauging the genetic changes occurring across globe artichoke micropropagation towards an appropriate variety registration and nursery production. Scientia Horticulturae 156:121-126. https://doi.org/10.1016/j.scienta.2013.03.018

Rossi V, De Paoli G (1992). Micropropagation of artichoke (Cynara scolymus). In: Bajaj YPS (Ed). Biotechnology in Agriculture and Forestry, Vol. 19. High-Tech and Micropropagation III, Springer-Verlag Berlin, Heidelberg pp 118-134.

Saccardo F, Jordan JR, Jordan A, Crinò P, Micozzi F, Lo Bianco C (2013). Innovative strategy to obtain F1 hybrids of globe artichoke. Acta Horticulturae 983:159-172. https://doi.org/10.17660/ActaHortic.2013.983.21

Saccardo F, Micozzi F, Di Lernia G, Piccioni C, Barba M, Pagnotta MA (2007). Virus free artichoke germplasm: qualiquantitative response of globe artichoke. Acta Horticulturae 730:375-379. https://doi.org/10.17660/ActaHortic.2007.730.49

Tavazza R, Papacchioli V, Ancora G (2004). An improved medium for in vitro propagation of globe artichoke (Cynara scolymus L.) cv. Spinoso sardo. Acta Horticulturae 660:91-97. https://doi.org/10.17660/ActaHortic.2004.660.10

Zucchi MI, Arizono H, Morais VA, Pelegrinelli Fungaro MH, Carneiro Vieira ML (2002). Genetic instability of sugarcane plants derived from meristem cultures. Genetics and Molecular Biology 25(1):91-96. https://doi.org/10.1590/S1415-47572002000100017
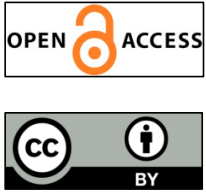

The journal offers free, immediate, and unrestricted access to peer-reviewed research and scholarly work. Users are allowed to read, download, copy, distribute, print, search, or link to the full texts of the articles, or use them for any other lawful purpose, without asking prior permission from the publisher or the author.

License - Articles published in Notulae Botanicae Horti Agrobotanici Cluj-Napoca are Open-Access, distributed under the terms and conditions of the Creative Commons Attribution (CC BY 4.0) License.

(C) Articles by the authors; UASVM, Cluj-Napoca, Romania. The journal allows the author(s) to hold the copyright/to retain publishing rights without restriction. 